\title{
"Everyone does it a bit differently!": Evidence for a positive relationship between micro-scale land-use diversity and plant diversity in hay meadows Short title: Relationship between plant and land-use diversity
}

\section{Róbert Kun ${ }^{\mathrm{a}}$ - Sándor Bartha ${ }^{\mathrm{b}, \mathrm{c}}$ - Ákos Malatinszkya - Zsolt Molnárb,c, Attila Lengyel - Dániel Babaid}

a Szent István University, Institute of Nature Conservation and Landscape Management, $\mathrm{H}$ 2103 Gödöllő, Páter K. 1, Hungary

b GINOP Sustainable Ecosystems Group, MTA Centre for Ecological Research, H-8237 Tihany, Klebelsberg Kuno u. 3. Hungary

c Institute of Ecology and Botany, MTA Centre for Ecological Research, H-2163, Vácrátót, Alkotmány u. 2-4. Hungary

d Institute of Ethnology, MTA Research Centre for the Humanities, H-1097 Budapest, Tóth Kálmán u. 4. Hungary

\begin{abstract}
:
High nature-value grasslands including mountain hay meadows are among the most species-rich habitats in Europe. Mountain hay meadows were developed and maintained by traditional, small-scale management systems having high micro-scale land-use diversity (MSLUD), i.e. the parcel-scale diversity of management elements which usually depend on individual decisions and family traditions of local farmers. Detailed studies documenting the effects of micro-scale land-use diversity on vegetation are absent. The main objectives of our study were to analyse the effect of micro-scale land-use diversity and evenness on local plant diversity and cover of the main plant functional types. Field work was carried out in the Gyimes region (Eastern Carpathians, Romania).

We conducted semi-structured interviews with the owners and managers of the studied meadow parcels in order to reveal the number of applied management elements $\left(\mathrm{N}_{\mathrm{m}}\right)$ and applied frequencies of these management elements (e.g. manuring, mowing, seed sowing and weed control) per parcel and to determine the three differently used hay meadow types from interviews. For quantifying MSLUD, the Shannon diversity formula was used, in the case of micro-scale land-use evenness (MSLUE), the original Pielou's evenness formula was applied. To document parcel-scale vegetation features, $4 \times 4$-meter quadrats were surveyed in every parcel.

We found significant differences in the $\mathrm{N}_{\mathrm{m}}$, MSLUD and MSLUE among the three management types. In models where MSLUD, MSLUE and $\mathrm{N}_{\mathrm{m}}$ were built in, we got better model fits and more parsimonious models than in cases where just management type was built into the models. Management elements (manuring, seed sowing) also had a significant effect on vegetation.

Our results highlight that micro-scale land-use diversity plays a significant role in the maintenance of plant diversity in traditional, small-scale farming systems. The main drivers behind the high micro-scale land-use diversity may be farmers' personal decisions and family traditions. We argue that for an adequate ecological understanding and conservation of these traditional, small-scale land-use systems, the development of adequate ways of evaluation as well as detailed studies of the effects of several different management elements and land-use diversity on vegetation are needed.
\end{abstract}

Keywords: mountain hay meadows, traditional management system, East-Central Europe, conservation, Shannon-diversity

\section{Introduction}

High nature-value semi-natural grasslands are considered among the most species-rich habitats in Europe, and are characteristic elements of many cultural landscapes (Fischer and Stöcklin, 1997; Fischer and Wipf, 2002; Myklestad and Saetersdal, 2004). The main reasons for the diversity of semi-natural grasslands are local, regional (Myklestad and Saetersdal, 2004), and historical factors (Marini et al., 2009), as well as landscape configuration (Janišová et al., 2014), and the traditional, long-term, small-scale, non-intensive land use (Babai and Molnár, 2014; Dorresteijn et al., 2015; Poschlod et al., 2005; Pykälä, 2000).

Traditional small-scale farming is characterised by low-input, labour-intensive practices on relatively small parcels. These systems have developed and maintained cultural landscapes with high natural, cultural and aesthetic values all over Europe (Dahlström et al., 2013; 
Plieninger et al., 2006). Grassland management is an important part of these systems, especially in cultural landscapes where grasslands are semi-natural (of woodland origin), and of high nature value (Babai et al., 2014; Vadász et al., 2016).

These traditional land-use systems almost disappeared from Western Europe during the second half of the 20th century (Marini et al., 2009; Meilleur, 1986; Plieninger et al., 2006). Their drastic decrease in Central and Eastern Europe was first caused by communist agricultural policies (Friedmann and McMichael, 1989), followed by political, economic, and social crises after 1990, and finally the diverse effects of the new regulatory systems after the accession to the European Union (e.g. Dorresteijn et al., 2015; Tudor, 2015). Diversity of land use decreased, while its intensity and spatial extent increased, or in many marginal landscapes land use was abandoned (Dengler et al., 2014; MacDonald et al., 2000; Niedrist et al., 2009; Ruprecht et al., 2010; Strijker, 2005). These processes had a negative effect on grassland diversity, causing homogenization of grassland vegetation (Csergő et al., 2013; Myklestad and Saetersdal, 2003; Spiegelberger et al., 2010).

Some of the small-scale land-use systems have avoided the abovementioned drastic changes in marginal, mainly mountainous landscapes of Europe (Babai and Molnár, 2014; von Glasenapp and Thornton, 2011; Tudor, 2015). The main reasons for their survival are economic and natural constraints (cf. Babai et al., 2015). Nature conservation measures also stimulated their survival, or in some cases, their partial revival (Dahlström et al., 2013). Surviving systems give us a chance to study the functioning of traditional small-scale land-use systems which are highly important for the conservation of these species-rich landscapes (Babai et al., 2015; Dahlström et al., 2013; Škodová et al., 2015; Söderström et al., 2001; Sutcliffe and Larkham, 2011). By their uniqueness and particular status, such landscapes are threatened in Europe (e.g., Alps - von Glasenapp and Thornton, 2011; North-Eastern Carpathians - Škodová et al., 2015).

Several publications highlight the positive impacts of certain management practices (especially the frequency of mowing, Tälle et al., 2018) on local plant diversity, and the possibly important role of management diversity (Marini et al., 2009; Meilleur, 1986; Myklestad and Sætersdal, 2004; Niedrist et al., 2009; Poschlod et al., 2005; Škodová et al., 2015; Söderström et al., 2001). However, we haven't found detailed studies measuring the effects of micro-scale land-use diversity (MSLUD), evenness (MSLUE) and number of management elements $\left(\mathrm{N}_{\mathrm{m}}\right)$ on vegetation. Fischer et al. (1996) and Poschlod et al. (2005) emphasize the importance of the small-scale decisions of farmers on the preservation of traditional landscape mosaics and local $a$ and $\beta$ diversity without providing field evidence. The special effect of land-use diversity on biological diversity has been only studied at a macro- or landscape scale and from a modelling perspective (e.g., Olsson et al., 2000; Yoshida and Tanaka, 2005; Fischer et al., 2008).

We studied MSLUD in a traditional cultural landscape in the Eastern Carpathians in Romania (Gyimes) with small-scale spatial mosaicity where species-rich hay meadows are managed by low-intensity traditional management by the local Hungarian Csángó community (Babai et al., 2014). Previous studies (Babai and Molnár, 2014; Babai et al., 2014) show that grassland management in Gyimes is similar to historical or recently abandoned systems of other mountainous landscapes in Europe (e.g. French Alps - Meilleur, 1986; Swiss Alps - Netting, 1981; Austrian Alps - von Glasenapp and Thornton, 2011; German Alps - Poschlod et al., 1998). Studying this surviving, still functioning system may help us to better understand one of the most important pillars of the concept of the European cultural landscape (Plieninger, $\mathrm{T}$. and Bieling (eds.), 2012), namely, the extensive traditional land-use system.

We have coined the term micro-scale land-use diversity (MSLUD), defined as the parcelscale diversity of management calculated by Shannon diversity from the different ratios of management elements, and have also coined the term micro-scale land-use evenness (MSLUE), defined as the parcel-scale evenness of management calculated by Pielou's evenness from the ratio of MSLUD to $\log \left(\mathrm{N}_{\mathrm{m}}\right)$. Types of these elements and the frequency of their use strongly depend on individual decisions and / or family traditions of local farmers (Babai et al., 2014) and are expected to cause plant diversity differences among parcels. 
The three main objectives of our study are the following:

- What forms number of management elements $\left(\mathrm{N}_{\mathrm{m}}\right)$, micro-scale land-use diversity (MLSUD) and micro-scale land-use evenness (MSLUE), and how are they built up?

- Are there any differences in number of management elements $\left(\mathrm{N}_{\mathrm{m})}\right.$, micro-scale landuse diversity (MSLUD) and micro-scale land-use evenness (MSLUE) between the main land-use management types?

- Do land-use management type, number of management elements $\left(\mathrm{N}_{\mathrm{m}}\right)$, micro-scale land-use diversity (MSLUD) and micro-scale land-use evenness (MSLUE) have a significant impact on local plant diversity and the cover of the main plant functional types?

In this paper we introduce the concept of micro-scale land-use diversity (MSLUD) as a determinant of plant diversity and composition of grasslands.

\section{Material and Methods}

\subsection{Study area}

The study area lies in Valea Rece (Hidegségpataka) in Lunca de Jos (Gyimesközéplok) in the Eastern Carpathians, Romania (coordinates: N: 46.628582, E: 25.958554). Elevation is 800$1550 \mathrm{~m}$ above sea level. The montane-boreal climate is modified by continentality, the mean annual temperature ranges from 4 to $6^{\circ} \mathrm{C}$, and the amount of annual precipitation from 700 to $1200 \mathrm{~mm}$ (Ilyés, 2007; Pálfalvi, 1995).The first settlers arrived in Gyimes in the middle of the 18th century (Babai et al., 2014; Ilyés, 2007). The area of Lunca de Jos is covered by forests $(30,2 \%)$, hay meadows $(30,4 \%)$, pastures $(36,4 \%)$, and arable lands $(3,0 \%)$ (Sólyom et al., 2011). The human population was 5307 in 2010 (http\#1). The majority of the local population are small-scale farmers, dealing primarily with cattle farming. The average farmland area is $3.8 \mathrm{ha}$ (Knowles, 2010; Sólyom et al., 2011), 0.97 ha is used as hay meadow on average in 3-5 parcels.

The area falls within the coniferous forest zone (acidophilous Picea forests - R4205) (Doniţâ et al., 2005). Vegetation of the hay meadows primarily belongs to Festuca rubra hay meadows (R3803) and acidofrequent grasslands (R3808), rarely to species-rich Nardus grasslands (R3609) (Doniţâ et al., 2005). Dominant or frequently occuring species are Arrhenatherum elatius, Trisetum flavescens, Dactylis glomerata, Poa pratensis, Salvia pratensis, Colchicum autumnale, Ranunculus acris, Taraxacum officinale, Trifolium pratense; regionally rare and / or characteristic species are Carlina acaulis, Dianthus compactus, Gentiana utriculosa, Gladiolus imbricatus, Trifolium pannonicum, Traunsteinera globosa, Trollius europaeus.

Local farmers divide their hay meadows into three types based on their use (Babai and Molnár, 2014): 1) inner (close to the settlement) hay meadows near the farmers' homes on valley floors on very gentle slopes, mown $2(3)$ times a year $(\mathrm{InFI}) ; 2$ ) inner hay meadows on steeper slopes with less intensive use (InSI); and 3) outer hay meadows on slopes farther from settlements, usually at higher altitudes, usually not manured, and mown once a year (Out) (Table 1).

The studied hay meadows have brown forest soil with $\mathrm{SiO}_{2}$ and metallic oxides, but most of them are nutrient rich as a consequence of land management (Table 1). Inner meadows (InFI and InSI) are manured every 1 to 3 years, with an average amount of $8833 \mathrm{~kg} / \mathrm{ha}$, with a relatively high standard deviation (SD $=3951 \mathrm{~kg} / \mathrm{ha}$ ), while outer hay meadows (Out) are manured rarely or not at all. The amount of nitrogen used yearly (based on laboratory evaluation of nutrient concentration of local averages of manure samples collected from parcels of land owners) that reaches the meadows ranges from 49.17 to $147.51 \mathrm{~kg}$ (mean: $73.76 \mathrm{~kg}$ ) ha/year, and phosphorus from 7.95 to $23.85 \mathrm{~kg}$ (mean: $11.93 \mathrm{~kg}$ ) ha/year, depending on the frequency of manuring (these values are far below the European average; cf. Ondersteijn et al., 2002) (Kun ined.). 
Table 1. Nitrogen, phosphorus and potassium concentrations (based on 8 soil samples per parcel, Kun unpubl.) and slope and altitude values of the three hay meadow management types.

\begin{tabular}{lcccc}
\multicolumn{1}{c}{ Characteristics } & $\begin{array}{c}\text { InFI } \\
\text { MEAN } \pm \text { SD }\end{array}$ & $\begin{array}{c}\text { InSI } \\
\text { MEAN } \pm \text { SD }\end{array}$ & $\begin{array}{c}\text { Out } \\
\text { MEAN } \pm \text { SD }\end{array}$ & p<0.05 \\
\hline $\mathrm{N}(\mathrm{mg} / \mathrm{kg})$ & $109.48 \pm 32.71 \mathrm{a}$ & $76.59 \pm 26.37 \mathrm{~b}$ & $77.02 \pm 33.18 \mathrm{~b}$ & $<0.001$ \\
$\mathrm{P}(\mathrm{mg} / \mathrm{kg})$ & $66.42 \pm 64.72 \mathrm{a}$ & $11.66 \pm 3.55 \mathrm{~b}$ & $9.39 \pm 2.43 \mathrm{~b}$ & $<0.001$ \\
$\mathrm{~K}(\mathrm{mg} / \mathrm{kg})$ & $156.53 \pm 73.92 \mathrm{a}$ & $169.89 \pm 99.21 \mathrm{a}$ & $164.73 \pm 55.35 \mathrm{a}$ & 0.402 \\
Slope angle $\left(^{\circ}\right)$ & $1.56 \pm 1.78 \mathrm{a}$ & $24.81 \pm 9.23 \mathrm{~b}$ & $24.14 \pm 3.56 \mathrm{~b}$ & $<0.001$ \\
Altitude (in meters) & $856.88 \pm 26.64 \mathrm{a}$ & $887.63 \pm 38.75 \mathrm{~b}$ & $959.14 \pm 72.11 \mathrm{c}$ & $<0.001$ \\
\hline
\end{tabular}

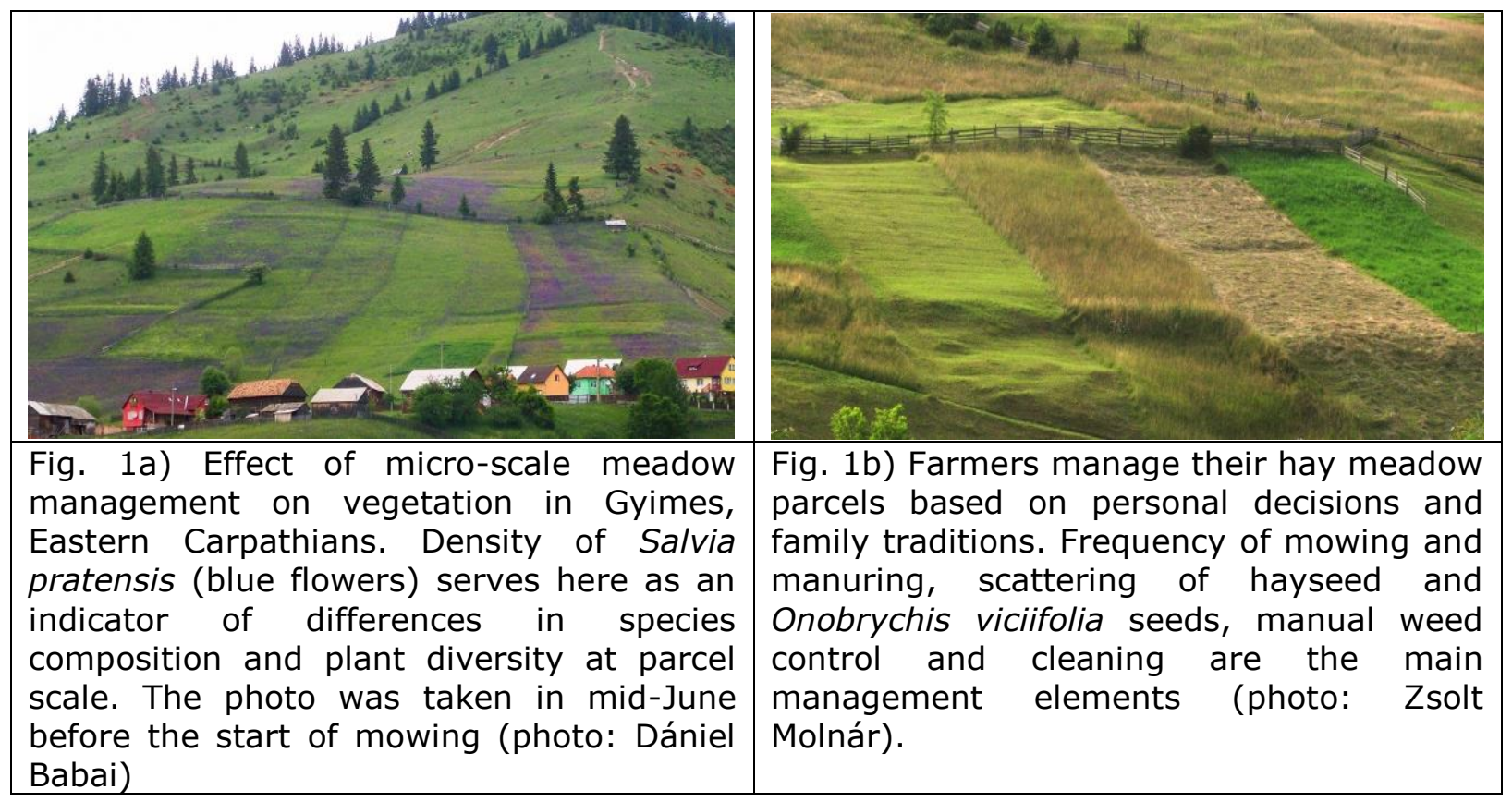

\subsection{Sampling methods}

We conducted semi-structured interviews with the owners and managers $(\mathrm{N}=16)$ of the studied parcels $(\mathrm{N}=23)$ in June 2013, with a focus on those land-use elements that are important for vegetation (based on Babai and Molnár, 2014; Babai et al., 2015). 81\% of the interviewees were farmers as a main occupation; their age varied between 20 and 85 years. The main questions of the interviews referred to the management type of the parcel according to the owner, frequency of mowing and manuring, presence or absence of hayseed and Onobrychis viciifolia sowing, manual weeding and clearing in the last 5 years.

Four sampling areas were selected in Valea Rece, each of them containing all three hay meadow management types, with similar exposure within one sampling area. The four sampling areas were chosen as close to each other as possible, and were similar in species composition.

Parcels were localized by the farmers during the interviews (precise location was determined using aerial photos if necessary). Boundaries of parcels were visible in the field, fenced or marked by stakes, anthills, etc. (for more details see Babai et al., 2014). Parcels were managed homogenously (if homogeneity was not unequivocally clear, the parcel was excluded from the analysis). In the case of outer hay meadows (Out), we sampled their zone which was less elevated and which was nearer to the other two types (Table 1) to avoid the impact of elevation on species composition. Therefore, the potential vegetation is the same in all three hay meadow management types. Sixty-nine $4 \times 4 \mathrm{~m}^{2}$ quadrats were surveyed in June 2013 . There were three types of parcels (InFI, InSI, Out, see above). Altogether 8 inner meadow parcels on valley floors, 8 parcels of inner meadows on slopes, and 7 parcels of outer meadows were surveyed. Three quadrats were placed randomly in each randomly chosen parcel. Percentage of geometrical cover values of all vascular plant species was estimated in all quadrats. 


\subsection{Formulating the concepts of micro-scale land use diversity and related data analysis}

As indicated above, parcels were classified into the three hay meadow management types by the owner farmers. Based on our interviews with the farmers, the most important management elements on the studied parcels were: 1) frequency of mowing, 2) frequency of manuring, 3) hayseed sowing, 4) sowing with Onobrychis seeds, 5) manual weed control, and 6 ) annual clearing. Based on the interviews, all management elements $(N=6)$ applied in the last 5 years were listed for all studied parcels, and with the help of the 6 different management elements we were able to delineate the three meadow types (InFI, InSI, Out) determined by local farmers as well. Management elements were quantified on a ratio scale according to the application frequency of a given management element applied by farmers on a parcel in the last 5 years. Number of management elements $\left(\mathrm{N}_{\mathrm{m}}\right)$ was quantified using the number of applied management elements for every given parcel (lowest $N_{m}=2$; highest $N_{m}=6$ ). MSLUD was calculated by the Shannon diversity formula, $\mathrm{H}=-\Sigma \mathrm{p}_{\mathrm{i}} * \log \mathrm{p}_{\mathrm{i}}$ (Peet 1975), $\mathrm{p}_{\mathrm{i}}$ being the proportion of $i$ th applied management element on every given parcel. We also introduced the related evenness term: MSLUE expressed as counted by the $\mathrm{H} / \mathrm{H}_{\max }$ formula, where $\mathrm{H}_{\max }=$ $\log \left(\mathrm{N}_{\mathrm{m}}\right)$ (Heip 1974, Peet 1975). Micro-scale land-use diversity (MSLUD) has been expressed by Shannon diversity at the parcel scale, and micro-scale land-use evenness (MSLUE) is expressed at the parcel scale. MSLUD was lower when just few management elements (e.g. $\mathrm{N}=2$ or $\mathrm{N}=3$ ) were applied on a given parcel with a relatively different ratio (e.g. there was just 1 dominant management element with higher frequency and few with lower frequency), and it was higher when several management elements (e.g. $N_{m}=5$ or $N_{m}=6$ ) were applied with similar frequency on a given parcel. There is an algebraic relationship among MSLUE, MSLUD and $N_{m}$. $\log \left(\mathrm{N}_{\mathrm{m}}\right)$ is the theoretical maximum of MSLUD, while MSLUE is the ratio between MSLUD and $\log \left(N_{m}\right)$. Thus, the more MSLUD approaches its theoretical maximum, the higher MSLUE is.

\subsection{Statistical analysis}

Species were classified into three main functional types: 'graminoids,' 'forbs,' and 'legumes.' Normality of every variable and their relationships of importance were checked by Shapiro-Wilk normality test. In the case of normally distributed variables we used ANOVA and Tukey HSD tests to test the difference between management types, while in the case of non-normal distribution, Kruskal-Wallis test and Dunn's post hoc test were applied with Bonferroni correction method to counteract the problem of multiple comparison. Linear mixed effect models were used to model the relationship between the three main predictors $\left(N_{m}, M S L U D\right.$, MSLUE) and plant diversity (species number, Shannon diversity) and plant functional types (i.e. graminoids and forbs percentage cover). In our models, management type, $\mathrm{N}_{\mathrm{m}}, \mathrm{MSLUD}$, and MSLUE were fixed factors and sampled site was a random factor. We also analysed separately the first three most important management elements determined by farmers (mowing, manuring seed sowing - management elements with strongest hypothetical explanatory power) in a model comparison. Every model comparison started with a model where management type was the only predictor and all following models were compared to this in parsimony and fit. Explanatory power and goodness of fit of the models were calculated with the help of unadjusted $R^{2}$ values and Akaike information criterion (AIC). Analyses were made in R 3.5.1 ( $R$ Core Team, 2018) software environment.

\section{Results}

\subsection{Micro-scale land-use diversity of the three main hay meadow management types}

We found differences in the frequency of management elements between the three hay meadow management types (Table A.1). The outer hay meadows (Out) were not manured (or only occassionally), and were mown only once a year, i.e., they had the lowest land-use intensity. Inner meadows on valley floors (InFI) and on slopes near the village (InSI) had more intensive management; the former were the most often manured and mown meadows. Some management elements were less confined to management types, such as sowing of hayseeds (collected seeds fallen from hay in the barn), sowing Onobrychis seeds, and manual control of 
weeds (e.g., Helleborus purpurascens, Veratrum album, Colchicum autumnale, young bushes and trees) using a hand scythe. Annual clearing of litter, twigs, ant and mole hills was a constant element of all three types (Table A.1).

Table 2. Number of management elements and micro-scale land-use diversity and evenness values of the three hay meadow management types in Gyimes, Eastern Carpathians.

\begin{tabular}{lcccc}
\hline Index / variable & $\begin{array}{c}\text { InFI } \\
\text { MEAN } \pm \text { SD }\end{array}$ & $\begin{array}{c}\text { InSI } \\
\text { MEAN } \pm \text { SD }\end{array}$ & $\begin{array}{c}\text { Out } \\
\text { MEAN } \pm \text { SD }\end{array}$ & p<0.05 \\
\hline $\mathrm{N}_{\mathrm{m}}$ & $4.00 \pm 1.11 \mathrm{ab}$ & $4.13 \pm 0.60 \mathrm{a}$ & $3.43 \pm 0.90 \mathrm{~b}$ & 0.034 \\
$\mathrm{MSLUD}$ & $1.75 \pm 0.35 \mathrm{a}$ & $1.93 \pm 0.29 \mathrm{ab}$ & $2.01 \pm 0.22 \mathrm{~b}$ & 0.036 \\
MSLUE & $0.90 \pm 0.03 \mathrm{a}$ & $0.93 \pm 0.05 \mathrm{~b}$ & $0.99 \pm 0.02 \mathrm{c}$ & $<0.001$ \\
\hline
\end{tabular}

There were significant differences in the number of management elements applied and MSLUD between outer hay meadows (Out) and the other two management types (InFI, InSI), while MSLUE was significantly different among all three management types (Table 2, Table A.1).

\subsection{Impact of hay meadow management types and micro-scale land-use diversity on local plant diversity and cover of functional types}

Plant diversity and cover of graminoid and legume species groups were significantly different among the three hay meadow management types (Table 3.). The quadrat level diversity of inner meadows in valley floors ( $\mathrm{InFl}$ ) was significantly smaller than the diversity of the other two types (InSI and Out). The plant diversity of inner meadows on slopes (InSI) was similar to outer hay meadows (Out) (Table 3 ). Total cover of legumes and graminoids was significantly different among the inner meadows on valley floors (InFI) and in outer meadows (Out) while inner meadows on slopes (InSI) showed intermediate values. Standard deviations of graminoids, legumes and forbs cover were moderately high or high in all cases, indicating considerable variations within each management type.

MSLUD and MSLUE explained parcel-scale plant diversity and cover of main plant functional types better than the number of management elements (Table 4). Models which had MSLUD, MSLUE and $\mathrm{N}_{\mathrm{m}}$ built in had better parsimony and stronger explanatory power in cases of species number, forbs, graminoids, than models where management type was the only predictor. Individual management practices (manuring, mowing and hayseed sowing) also had a considerable effect on plant diversity and plant functional types cover (e.g. manuring on Shannon diversity, seed sowing on Shannon diversity and on cover of graminoids and forbs for more details see: Table A.2). MSLUE had a stronger effect on graminoid and legume cover and species number than on Shannon diversity (Table 4). MSLUD had a significant and stronger positive relationship with species number than MSLUE (Fig. 2). MSLUE had a negative effect on graminoid cover and a positive effect on legume cover (Fig. 2).

Table 3. Shannon diversity, species number and cover values of main functional groups in the three hay meadow management types in Gyimes, in the Eastern Carpathians.

\begin{tabular}{lcccc}
\hline Index / variable & $\begin{array}{c}\text { InFI } \\
\text { MEAN } \pm \text { SD }\end{array}$ & $\begin{array}{c}\text { InSI } \\
\text { MEAN } \pm \text { SD }\end{array}$ & $\begin{array}{c}\text { Out } \\
\text { MEAN } \pm \text { SD }\end{array}$ & p<0.05 \\
\hline Shannon diversity & $2.25 \pm 0.29 \mathrm{a}$ & $2.84 \pm 0.11 \mathrm{~b}$ & $2.63 \pm 0.27 \mathrm{~b}$ & $<0.001$ \\
Number of species & $25.58 \pm 6.06 \mathrm{a}$ & $36.04 \pm 7.66 \mathrm{~b}$ & $40.10 \pm 8.51 \mathrm{~b}$ & $<0.001$ \\
Forbs cover & $45.08 \pm 17.43 \mathrm{a}$ & $52.02 \pm 13.92 \mathrm{a}$ & $55.59 \pm 16.92 \mathrm{a}$ & 0.100 \\
Graminoids cover & $52.20 \pm 19.75 \mathrm{a}$ & $40.04 \pm 14.71 \mathrm{ab}$ & $32.01 \pm 21.91 \mathrm{~b}$ & 0.003 \\
Fabaceae cover & $11.85 \pm 9.00 \mathrm{a}$ & $18.34 \pm 10.03 \mathrm{ab}$ & $27.73 \pm 19.45 \mathrm{~b}$ & $<0.001$ \\
\hline
\end{tabular}

Table 4. Explanatory variables were meadow type $(\boldsymbol{T})$, effect of number of management elements $(\boldsymbol{N})$, micro-scale land-use diversity $(\boldsymbol{D})$, and evenness $(\boldsymbol{E})$. Effects of explanatory variables on plant diversity variables and functional types were measured and compared by $R^{2}$ and Akaike information criterion (AIC) values. 


\begin{tabular}{|c|c|c|c|c|c|c|c|c|c|c|}
\hline & \multicolumn{2}{|c|}{$\begin{array}{l}\text { Species } \\
\text { number }\end{array}$} & \multicolumn{2}{|c|}{$\begin{array}{l}\text { Shannon } \\
\text { diversity }\end{array}$} & \multicolumn{2}{|c|}{ Graminoids } & \multicolumn{2}{|c|}{ Forbs } & \multicolumn{2}{|c|}{ Fabaceae } \\
\hline & AIC & $\mathrm{R}^{2}$ & AIC & $\mathrm{R}^{2}$ & AIC & $\mathrm{R}^{2}$ & AIC & $\mathrm{R}^{2}$ & AIC & $\mathrm{R}^{2}$ \\
\hline$T$ & 447.79 & 0.38 & 42.29 & 0.29 & 559.39 & 0.15 & 557.91 & 0.06 & 548.62 & 0.18 \\
\hline D & 456.11 & 0.22 & 48.15 & 0.03 & 567.18 & 0.01 & 562.96 & 0.00 & 559.12 & 0.01 \\
\hline $\boldsymbol{E}$ & 455.85 & 0.12 & 42.87 & 0.08 & 560.19 & 0.12 & 558.94 & 0.01 & 551.44 & 0.10 \\
\hline $\boldsymbol{N}$ & 464.30 & 0.03 & 50.06 & 0.04 & 568.41 & 0.04 & 563.21 & 0.06 & 560.52 & 0.03 \\
\hline$T+D$ & 440.90 & 0.45 & 45.93 & 0.28 & 554.32 & 0.15 & 552.76 & 0.08 & 544.82 & 0.18 \\
\hline$T+E$ & 440.42 & 0.38 & 41.66 & 0.29 & 549.80 & 0.16 & 549.13 & 0.06 & 540.71 & 0.18 \\
\hline$T+N$ & 446.73 & 0.38 & 46.49 & 0.32 & 556.16 & 0.16 & 554.23 & 0.10 & 546.94 & 0.18 \\
\hline$T+D+E$ & 431.86 & 0.48 & 45.10 & 0.28 & 544.26 & 0.16 & 543.93 & 0.08 & 536.62 & 0.18 \\
\hline$T+D+N$ & 439.95 & 0.45 & 50.17 & 0.31 & 551.07 & 0.16 & 549.09 & 0.12 & 543.10 & 0.18 \\
\hline$T+E+N$ & 439.37 & 0.37 & 45.75 & 0.32 & 546.42 & 0.17 & 545.54 & 0.10 & 538.94 & 0.18 \\
\hline$T+D+E+N$ & 431.10 & 0.47 & 49.22 & 0.31 & 540.81 & 0.18 & 540.27 & 0.11 & 534.79 & 0.18 \\
\hline
\end{tabular}

(a)

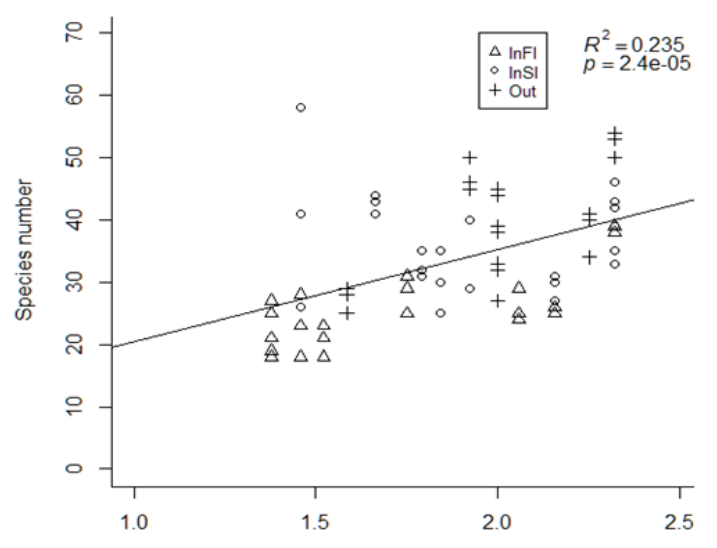

(c)

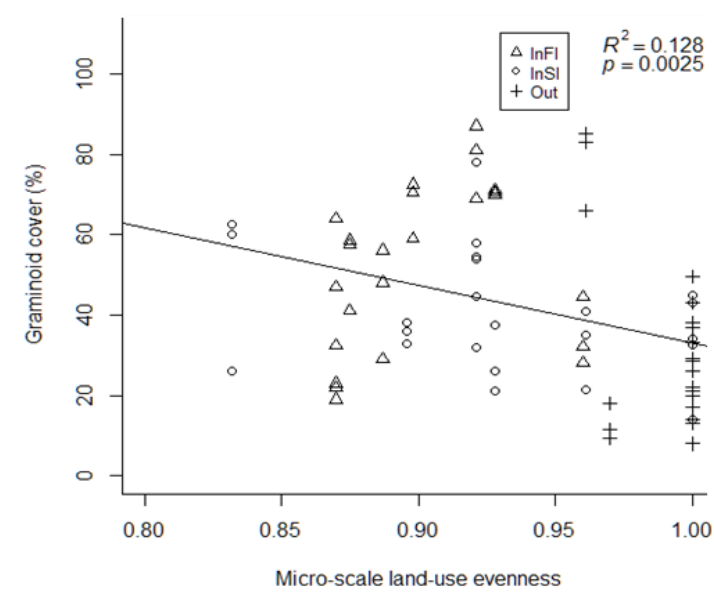

(b)

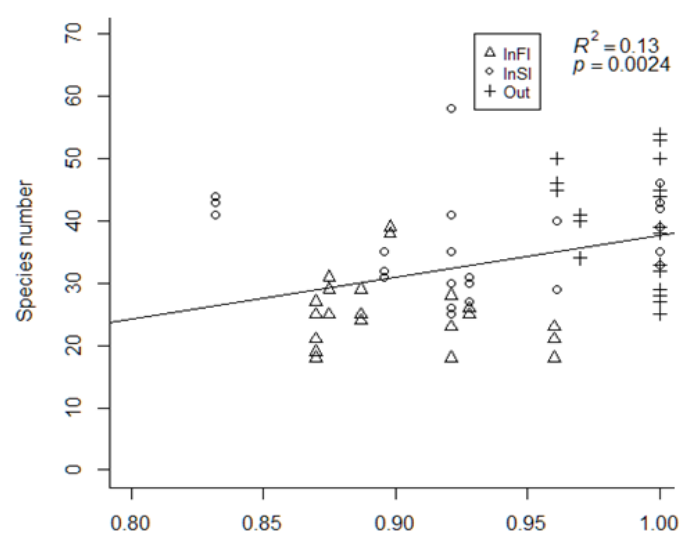

(d)

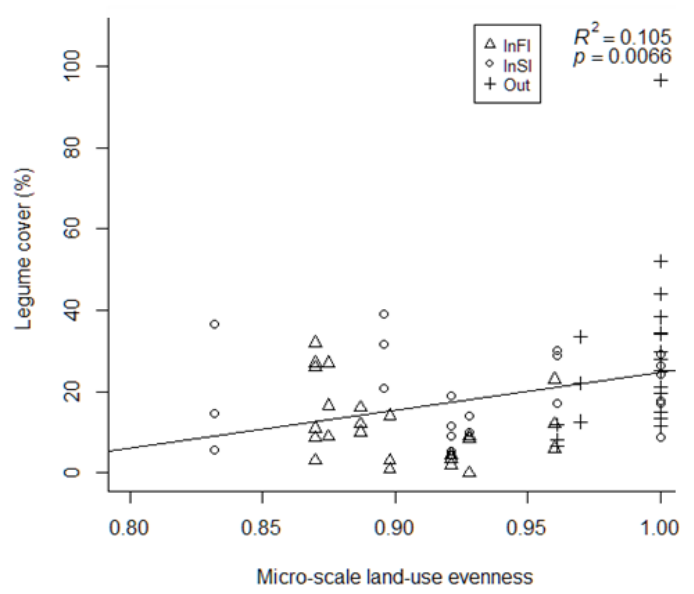

Fig. 2. Linear relatioships with best fits. Effect of micro-scale land-use diversity (a) and evenness (b) on species number and effect of evenness on cover of graminoids (c) and legumes (d) in Gyimes, Eastern Carpathians.

\section{Discussion}

\subsection{Micro-scale land-use diversity and its impact on local vegetation}

Number of applied management elements $\left(\mathrm{N}_{\mathrm{m}}\right)$, micro-scale land-use diversity (MSLUD) and evenness (MSLUE) were different among the three main hay meadow management types in the study area (Table 2, Table A.1). Additionally, MSLUD and MSLUE had a significant impact on local (quadrat scale) plant diversity and the cover of graminoids and forbs (Fig. 2, Table 4). 
From model comparisons it was clear that MSLUD and MSLUE had a considerable effect on the parsimony of models compared with simpler models where management type was the only predictor (Table 4). These results suggest that MSLUD and MSLUE as well as the composition of parcel-scale management may play a significant role in the development and maintenance of plant diversity in traditional, non-intensive, small-scale farming systems. Several management elements of the studied hay meadows were confined to certain types, the major difference being the frequency of mowing, manuring (being less intensive on outer meadows) and hayseed sowing (Table A.1). Clearing management element was present on every parcel while other elements appeared rather randomly (e.g., hayseed sowing). Manuring rates and hayseed sowing had a significant effect on vegetation independently, especially on Shannon diversity, on graminoids and forbs cover (Table A.2). There are other important management elements which contribute to land-use composition and enhance land-use diversity (meadow cleaning, weed control and Onobrychis seed sowing) and thereby plant diversity (Fig. 2, Table A.1). Babai and Molnár (2014) and our interviews suggest that the main drivers behind MSLUD in Gyimes are farmers' personal decisions, family traditions, labour and work organisation of the farm, distance, exposure and accessibility of the parcels. An increase in human population in the landscape during the last century resulted in fragmentation of the parcels (mean size < 1 ha; Babai et al., 2014). This has led to the development of a small-scale traditional 'precision' management system with careful manuring, hayseed sowing, manual weed control, etc. (Babai et al., 2015).

MSLUD had a visible impact on the vegetation in Gyimes (see Fig. 1). Plant diversity, species number and legume cover were lowest in the most intensively managed and most productive meadows in valley floors (InFls), while graminoid cover was the highest with relatively high standard deviations (Table 3). Farmers in Gyimes are aware of the importance of the proportion of graminoids, forbs and legumes as these considerably affect hay quality, grassy hay being preferred by horses, while forb-rich hay by cattle (Babai and Molnár, 2014). Inner meadows are deliberately managed differently because they are highly valued for the high quality second growth cut in late summer (Babai et al., 2015).

Diversity and evenness of management seemed to be a more important factor affecting plant diversity and composition than the number of management elements per parcel in itself. MSLUD had a stronger effect on species number than evenness (MSLUE), while MSLUE had a stronger effect on the cover of graminoids and legumes than land-use diversity (MSLUD) (Fig. 2). MSLUD and MSLUE as indices of the parcel-scale composition of management were better predictors in our study than the $\mathrm{N}_{\mathrm{m}}$, where only the parcel-scale number of management elements was taken into consideration. Ecological mechanisms behind these patterns are not yet completely clear.

Hayseed sowing was most common on inner meadows on valley floors and on slopes and had a considerable effect on Shannon diversity, forbs and graminoids cover (Table A.2). This practice may significantly contribute to the propagule dispersion in this landscape and may have a significant positive impact on species number (Babai et al., 2015). Hayseed sowing (from local seed sources) is not a widespread management element in European hay meadows today (Babai and Molnár, 2014; Ivașcu et al., 2016) but might have been a common practice in the past, until the $19^{\text {th }}$ century (Poschlod and Wallis de Vries, 2002; Poschlod and Biewer, 2005; and unpubl. data of the authors). Onobrychis viciifolia seed sowing was also a common practice in our Eastern Carpathian study area. Onobrychis improves forage quality, helps equalize the forage value of the parcels (Babai et al., 2015), and as it is not applied to all parcels, it adds to land-use diversity. Exact timing of mowing can also be a key factor affecting local plant diversity. Several days' or 1-2 weeks' difference in mowing time among years certainly affects the composition of seeds fallen back in that year to that parcel. However, correct documentation and quantification of this management practice was not possible (but see an exceptional case study from England, http\#2). Calculating long-term yearly differences in average (!) mowing times would be a first step to document this diversity.

Although plant diversity significantly differed between hay meadow management types, this diversity was relatively high in all three types (Table 3). Besides the relatively low intensity of 
traditional farming (Babai et al., 2015; cf. Maurer et al., 2006; Niedrist et al., 2009), some management elements (e.g. hayseed sowing), land-use diversity and evenness might have contributed to this unexpected homogenous pattern. We emphasize that even the most intensively used parcels in Gyimes had high species diversity compared to most European hay meadows (see e.g. Niedrist et al., 2009; Plantureux et al., 2005).

\subsection{Nature conservation, agricultural regulations and micro-scale land-use diversity}

According to our interviews with local farmers and previous studies (Babai and Molnár, 2014; Babai et al., 2014; 2015), the main objective of the well-developed traditional small-scale hay meadow management system in Gyimes is to increase the reliability of a natural resource provision, i.e. to ensure the necessary hay fodder for the winter and decrease inter-annual fluctuations in its quantity and quality. The relatively high species diversity of these meadows is actually only a 'by-product' of their activities.

Farmers in Gyimes use their hay meadows non-intensively due to natural, lifestyle and regulatory constraints. Diversity of use is increased by personal decisions emerging from family traditions. The optimal ratio of management elements and enhancement of MSLUD and MSLUE can help farmers sustain the level of quality of hay and can help increase species diversity. Land abandonment, a major cause of meadow degradation Europe-wide (Galvánek and Lepš, 2008; MacDonald et al., 2000; Plieninger et al., 2013; Poschlod et al., 2005; Ruprecht et al., 2010) results in decreasing plant diversity in this region also (Csergő et al., 2013). However, due to the economically marginal situation of the local community and the availability of the European Union agricultural subsidies promoting continued land use, land abandonment is less prominent in this landscape than in the adjacent regions (Demeter and Kelemen, 2012; Sólyom et al., 2011) (but it exists in this landscape as well). The main reason for this is that subsidies provide one of the main sources of cash for local livelihoods in this region (Babai et al., 2015; Sólyom et al., 2011).

Agricultural regulations and subsidies, however, have negative effects as well. Mowing on inner meadows in the valley floors and slopes has become more uniform in recent years and has shifted to a later date due to regulations. These changes are economically disadvantageous to family farms, since they can only harvest the hay late, in a sub-optimal state (Babai et al., 2015). Hence, regulations can decrease MSLUD and thus can cause a decrease in plant diversity in the future. For this reason, it would be very important to monitor how MSLUD would change as a result of planned regulation and through this, how it would affect plant diversity.

In the Gyimes region this effect (i.e., the more uniform time of mowing) has become even more widespread with the recent introduction of small mowing machines. On the other hand, mowing machines slowed down the pace of abandonment since they make harvesting more efficient, thus, farmers continue their management (about $90 \%$ of mountain hay meadows are still managed; Demeter and Kelemen, 2012).

Similarly to other European examples (Romania - Dahlström et al., 2013; Switzerland Fischer and Wipf, 2002; von Glasenapp and Thornton, 2011; France - Meilleur, 1986), local people of Gyimes have adapted their complex land-use system to the potentials and constraints of their natural environment, building on their deep traditional ecological knowledge (Babai et al., 2014). European Union and government regulations should take these local traditions into consideration when developing regulatory systems (Babai et al., 2015) to maintain the special, high MSLUD in such traditional cultural landscapes (Molnár and Berkes, 2018). Furthermore, we argue that for an adequate ecological understanding and conservation of these diverse small-scale land-use systems, detailed studies of the combined effects of all the different management elements on vegetation (including their variability and diversity) are needed (cf. Vadász et al., 2016). Developing better ways of quantifying MSLUD (e.g., using diversity indices and determining their sensitivity to special situations) is a major task for future research.

Our closing quote from a local farmer indicates that traditional farmers in Gyimes are aware of the high micro-scale land-use diversity of their management system, and that their deep traditional understanding of vegetation dynamics is still alive: "If there would be no fence, the 
parcel boundaries would still be visible, since everyone does it (the management of the parcels) a bit differently!" Let's help them continue!

\section{Acknowledgements}

We are grateful for our helpful local interviewees: Csaba Ambrus, Virág Blága, Dezső Boczony, Ibolya Boczony, Ervin Bodor, Dénes Csilip, Károly Ferencz, Lenke Mária Ferencz, László Gábor, András Lajos, Anna Molnár, Károly Molnár, Mária Molnár, Bettina Prezsmer, Károly Prezsmer, Mihály Prezsmer, István Tankó, Antal Tímár, Dezső Tímár, Gyula Tímár, Gyula János Tímár, Piroska Tímár, Zoltán Molnár, and János Tímár.

We also thank Ábel Molnár, Attila Barczi, Dénes Saláta, Csaba Centeri, Klára Virágh, András Kelemen, Orsolya Valkó, Béla Harman, Péter Ragályi, Michal Hejcman, Jan Lepš, Thomas Fricke, and Samantha Charman for their help in field work and analyses.

This work was supported by the Szent István University Kutató Kari Pályázat (MKK-791-10-34/2014) and by the Szent István University, KTDI (Robert Kun); by GINOP-2.3.2-15-2016-00019 project (Zsolt Molnár, Sándor Bartha) furthermore by the MTA Postdoctoral Scholarship (PPD008/2017) (Daniel Babai).

\section{References}

Babai, D., Molnár, Zs., 2014. Small-scale traditional usement of highly species-rich grasslands in the Carpathians. Agric. Ecosyst. Environ. 182, 123-130.

Babai, D., Molnár, Á., Molnár, Zs., 2014. "Ahogy gondozza, úgy veszi hasznát" Hagyományos ökológiai tudás és gazdálkodás Gyimesben. [Traditional ecological knowledge and land use in Gyimes (EasternCarpathians)]. Research Centre for the Humanities, Ecological Research Centre, Hungarian Academy of Sciences, Budapest-Vácrátót, Hungary.

Babai, D., Tóth, A., Szentirmai, I., Biró, M., Máté, A., Demeter, L., Szépligeti, M., Varga, A., Molnár, Á., Kun, R., Molnár, Zs., 2015. Do conservation and agri-environmental regulations effectively support traditional small-scale farming in East-Central European cultural landscapes? Biod. Conserv. 24, 3305-3327.

Csergő, A., Demeter, L., Turkington, R., 2013. Declining diversity in abandoned grasslands of the Carpathian mountains: do dominant species matter? PloS One 8, e 73533.

Dahlström, A., Iuga, A., Lennartsson, T., 2013. Managing biodiversity rich hay meadows in the EU: a comparison of Swedish and Romanian grasslands, Environ. Conserv. 40, 194-205.

Demeter, L., Kelemen, A., 2012. Quantifying the abandonment of mountain hay meadows in the Eastern Carpathians. EFNCP Report, $21 \mathrm{pp}$.

Dengler, J., Janišová, M., Török, P., Wellstein, C., 2014. Biodiversity of Palaearctic grasslands: a synthesis. Agric. Ecosyst. Environ. 182, 1-14.

Doniţâ, N., Popescu, A., Paucâ-Comânescu, M., Mihâilescu, S., Biriş, I.A., 2005. Habitatele din România [Romania's Habitats]. Bucharest, 442 pp.

Dorresteijn, I., Loos, J., Hanspach, J., Fischer, J., 2015. Socioecological drivers facilitating biodiversity conservation in traditional farming landscapes. Ecosyst. Health Sustain. 1, 1-9.

Fischer, M., Stöcklin, J., 1997. Local extinctions of plants in remnants of extensively used calcareous grasslands 1950-1985. Conserv. Biol. 11, 727-737.

Fischer, M., Wipf, S., 2002. Effect of low-intensity grazing on the species-rich vegetation of traditionally mown subalpine meadows. Biol. Conserv. 104, 1-11.

Fischer, M., Rudmann-Maurer, K., Weyand, A., Stöcklin, J., 2008. Agricultural Land Use and Biodiversity in the Alps. MT Res. Dev. 28, 148-155.

Fischer, S.F., Poschlod, P., Beinlich, B., 1996. Experimental studies on the dispersal of plants and animals on sheep in calcareous grasslands. J. of Appl. Ecol. 33, 1206-1222.

Friedmann, H., McMichael, Ph., 1989. Agriculture and the State System: The rise and decline of national agricultures, 1870 to the present. Sociol. Rural. 29, 93-117.

Heip, C. 1974. A new index measuring evenness. Journal of the Marine Biological Association of the United Kingdom. 54, 555-557.

Galvánek, D., Lepš, J., 2008. Changes of species richness pattern in mountain grasslands: abandonment versus restoration. Biodiv. Conserv. 17, 3241-3253.

von Glasenapp, M., Thornton, T.F., 2011. Traditional ecological knowledge of Swiss alpine farmers and their resilience to socioecological change. Hum. Ecol. 39, 769-781.

Ilyés, Z., 2007. A tájhasználat változásai és a történeti kultúrtáj 18-20. századi fejlődése Gyimesben. [Landscape changes and the 18-20th century development of the historical cultural landscape in Gyimes]. Eszterházy Károly High School, Eger, Hungary, 191 pp. 
Ivascu, C.M., Öllerer, K., Rakosy, L., 2016. The traditional perceptions of hay and hay-meadow management in a historical village from Maramureș county, Romania. Martor 21, 37-51.

Janišová, M., Michalcová, D., Bacaro, G., Ghisla, A., 2014. Landscape effects on diversity of semi-natural grasslands. Agric. Ecosyst. Environ. 182, 47-58.

Knowles, B., 2010. Mountain Hay Meadows: the Romanian Context and the Effects of Policy on High Nature Value Farming, in Knowles, B. (Ed.), Mountain hay meadows - hotspots of biodiversity and traditional culture. http://www.mountainhaymeadows.eu/online publication/02-mountain-haymeadows-the-romanian-context-and-the-effects-of-policy-on-high-nature-value-farming.html (accessed 11 Sept 2018).

MacDonald, D., Crabtree, J.R., Wiesinger, G., Dax, T., Stamou, N., Fleury, P., Lazpita, J.G., Gibon, A., 2000. Agricultural abandonment in mountain areas of Europe: environmental consequences and policy response. J. Environ. Manag. 59, 47-69.

Marini, L., Fontana, P., Klimek, S., Battisti, A., Gaston, K.J., 2009. Impact of farm size and topography on plant and insect diversity of managed grasslands in the Alps. Biol. Conserv. 142, 394-403.

Maurer, K., Weyand, A., Fischer, M., Stöcklin, J., 2006. Old cultural traditions, in addition to land use and topography, are shaping plant diversity of grasslands in the Alps. Biol. Conserv. 130, 438-446.

Meilleur, B., 1986. Alluetain Ethnoecology and traditional economy: The procurement and production of plant resources in the Northern French Alps. PhD thesis, University of Washington, Washington, 467 pp.

Molnár Zs., Berkes F., 2018. Role of traditional ecological knowledge, in Paracchini, M.L., Zingari, P.C., Blasi, C., (Eds.), Reconnecting Natural and Cultural Capital. Contributions from Science and Policy. Luxembourg: Publications Office of the European Union, pp. 183-193.

Myklestad, $\AA$., Sætersdal, M., 2003. Effects of reforestation and intensified land use on vascular plant species richness in traditionally managed hay meadows. Ann. Bot. Fenn. 40, 432-441.

Myklestad, А., Sætersdal, M., 2004. The importance of traditional meadow usement techniques for conservation of vascular plant species richness in Norway. Biol. Conserv. 118, 133-139.

Netting, R. McC., 1981. Balancing on an Alp. Ecological change \& continuity in a Swiss mountain community. Cambridge University Press, US, 278 pp.

Niedrist, G., Tasser, E., Lüth, Ch., Dalla Via, J., Tappeiner, U., 2009. Plant diversity declines with recent land use changes in European Alps. Plant Ecol. 202, 195-210.

Olsson, E. G. A., Austrheim, G., Grenne, S. N., 2000. Landscape change patterns in mountains, land use and environmental diversity, Mid-Norway 1960-1993. Landscape Ecol., 15, 155-170.

Ondersteijn, C.J.M., Beldman, A.C.G., Daatselaar, C.H.G., Giesen, G.W.J., Huirne, R.B.M., 2002. The Dutch Mineral Accounting System and the European Nitrate Directive: implications for $\mathrm{N}$ and $\mathrm{P}$ usement and farm performance, Agric. Ecosyst. Environ. 92, 283-296.

Pálfalvi, P., 1995. A Gyimesi-hágó (1164 m) környékének florisztikai vázlata. [Floristic sketch of the surroundings of the Gyimes Pass $(1164 \mathrm{~m}$ )]. Múzeumi Füzetek (Az Erdélyi Múzeum Egyesület Természettudományi és Matematikai Szakosztályának Közleményei) 4, 107-114.

Peet, R. K. 1975. Relative diversity indices. Ecology. 56, 496-498.

Plantureux, S., Peeters, A., McCracken, D., 2005. Biodiversity in intensive grasslands: Effect of usement, improvement and challenges. Agron. Res. 3, 153-164.

Plieninger, T., Höchtl, F., Spek, T., 2006. Traditional land-use and nature conservation in European rural landscapes. Environ. Scien. Pol. 9, 317-321.

Plieninger, T., Bieling, C. (Eds.), 2012. Resilience and the cultural landscape: understanding and managing change in human-shaped environments. Cambridge University Press.

Plieninger, T., Gaertner, M., Hui, C., Huntsinger, L., 2013. Does land abandonment decrease species richness and abundance of plants and animals in Mediterranean pastures, arable lands and permanent croplands? Environ. Evid. 2, 1-7.

Poschlod, P., Wallis de Vries, M.F., 2002. The historical and socioeconomic perspective of calcareous grasslands - lessons from the distant and recent past, Biol. Conserv. 104, 361-376.

Poschlod, P., Biewer, H., 2005. Diaspore and gap availability are limiting species richness in wet meadows. Fol. Geob. 40, 13-34.

Poschlod, P., Kiefer, S., Tränkle, U., Fischer, S., Bonn, S., 1998. Plant species richness in calcareous grasslands as affected by dispersability in space and time. Appl Veg Sci 1, 75-90.

Poschlod, P., Bakker, J.P., Kahmen, S., 2005. Changing land use and its impact on biodiversity. Bas. Appl. Ecol. 6, 93-98.

Pykälä, J., 2000. Mitigating Human Effects on European Biodiversity through Traditional Animal Husbandry. Conserv. Biol. 14, 705-712.

R Core Team 2016. R: A language and environment for statistical computing. R Foundation for Statistical Computing, Vienna, Austria. https://www.R-project.org/ (accessed 11 Sept 2018) 
Ruprecht, E., Enyedi, M.Z., Eckstein, R.L., Donath, T.W., 2010. Restorative removal of plant litter and vegetation 40 years after abandonment enhances re-emergence of steppe grassland vegetation. Biol. Conserv. 143, 449-456.

Škodová, I., Janišová, M., Hegedüšová, K., Borsukevych, L., Smatanová, J., Kish, R., Píš, V., 2015. Submontane semi-natural grassland communities in the Eastern Carpathians (Ukraine). Tuexen 35, 355380.

Söderström, B., Svensson, B., Vessby, K., Glimskär, A., 2001. Plants, insects and birds in semi-natural pastures in relation to local habitat and landscape factors. Biodiv. Cons. 10, 1839-1863.

Sólyom, A., Knowles, B., Bogdán, J., Rodics, G., Biró, R., Nyírő, G., 2011. Small-scale farming in the Pogány-Havas Region of Transylvania. Farming statistics, agricultural subsidies, the future of farming. Final Report. Pogány-Havas Kistérségi Társulat, Csíkszereda, 97 pp.

Spiegelberger, T., Deléglise, C., Dedanieli, S., Bernard-Brunet, C., 2010. Resilience of acid subalpine grassland to short-term liming and fertilisation, Agric. Ecosyst. Environ. 137, 158-162.

Strijker, D., 2005. Marginal lands in Europe-causes of decline. Bas. Appl. Ecol. 6, 99-106.

Sutcliffe, L., Larkham, K., 2011. Monitoring High Nature Value Grassland in Transylvania, in Knowles, B. (Ed.), Mountain hay meadows - hotspots of biodiversity and traditional culture. https://www.mountainhaymeadows.eu/online_publication/09-monitoring-high-nature-valuegrassland-in-transylvania-romania.html (accessed 11 Sept 2018).

Tälle, M., Deák, B., Poschlod, P., Valkó, O., Westerberg, L., Milberg, P., 2018. Similar effects of different mowing frequencies on the conservation value of semi-natural grasslands in Europe. Biodiv. Cons. 27, $1-25$.

Tudor, M. M., 2015. Small scale agriculture as a resilient system in rural Romania. Stud. Agric. Econom. 117, 27-34.

Vadász, Cs., Máté, A., Kun, R., Vadász-Besnyői, V., 2016. Quantifying the diversifying potential of conservation usement systems: An evidence based conceptual model for managing species-rich grasslands. Agric. Ecosyst. Environ. 234, 134-141.

Yoshida, T., Tanaka, K., 2005. Land-use diversity index: a new means of detecting diversity at landscape level. Landsc. Ecol. Engin. 1, 201-206.

Web references

http\#1: Erdély etnikai és felekezeti statisztikái a népszámlálási adatok alapján, 1852-2011. [Ethnic and denominational statistics of (1850-1992)] http://nepszamlalas.adatbank.transindex.ro/index.php?keres=gyimesk $\% F 6 z \% E 9 p l o k \& m e g y e=0 \& x=$ 0\&y=0\&pg =telepuleslista/ (accessed 11 Sept 2018).

http\#2: Half-hidden in the herbage - John Rodwell, Vijfde lustrum Plantensociologische Kring Nederland, Nijmegen, $24 \quad$ January 2015 http://www.stratiotes.net/index.php?option=com filecabinet\&view=files\&id=42\&Itemid=5 


\section{Appendix}

Table 1. Management elements of the three hay meadow types at parcel scale $(N=23)$. Black cells: presence; white cells: absence of a given management element in the last 5 years. In the case of manuring, four levels, in the case of mowing, two levels were used to distinguish different intensity regimes.

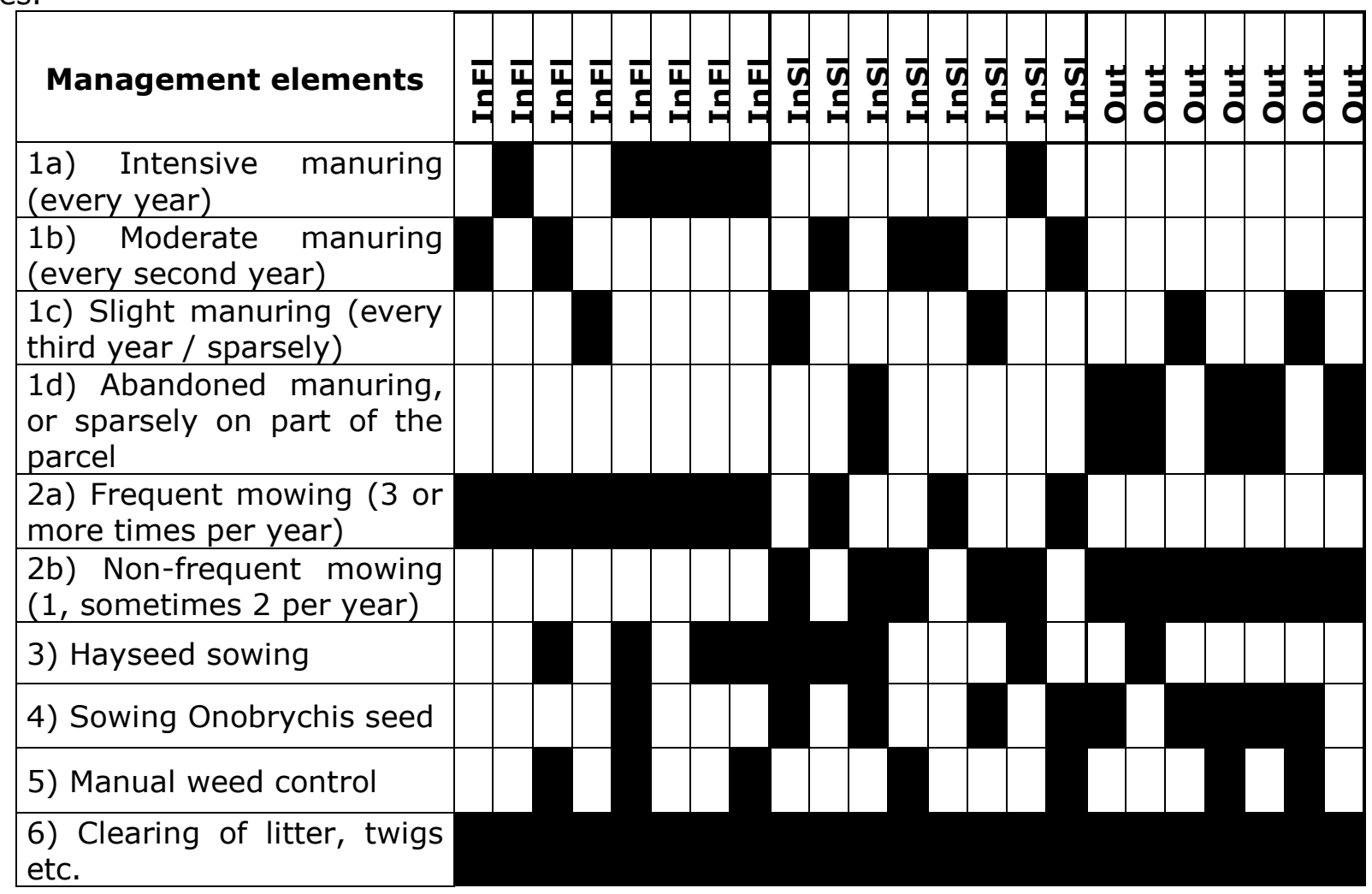

Table 2. Explanatory variables were meadow type (T), manuring intensity (man), mowing intensity (frequency) (mow), and hayseed sowing (seed). Effects of explanatory variables on plant diversity variables and fuctional types were measured and compared by $\mathrm{R}^{2}$ and Akaike information criterion (AIC) values.

\begin{tabular}{|c|c|c|c|c|c|c|c|c|c|c|}
\hline & \multicolumn{2}{|c|}{$\begin{array}{l}\text { Species } \\
\text { number }\end{array}$} & \multicolumn{2}{|c|}{$\begin{array}{l}\text { Shannon } \\
\text { diversity }\end{array}$} & \multicolumn{2}{|c|}{ Graminoids } & \multicolumn{2}{|c|}{ Forbs } & \multicolumn{2}{|c|}{ Fabaceae } \\
\hline & AIC & $\mathrm{R}^{2}$ & AIC & $\mathrm{R}^{2}$ & AIC & $\mathrm{R}^{2}$ & AIC & $\mathrm{R}^{2}$ & AIC & $\mathrm{R}^{2}$ \\
\hline $\boldsymbol{T}$ & 447.79 & 0.38 & 42.29 & 0.29 & 559.39 & 0.15 & 557.91 & 0.06 & 548.62 & 0.18 \\
\hline man & 459.60 & 0.20 & 42.88 & 0.23 & 565.68 & 0.14 & 562.56 & 0.09 & 558.76 & 0.08 \\
\hline mow & 458.05 & 0.20 & 44.45 & 0.16 & 565.93 & 0.08 & 562.20 & 0.05 & 556.46 & 0.09 \\
\hline seed & 463.33 & 0.02 & 47.00 & 0.09 & 555.29 & 0.37 & 556.63 & 0.20 & 553.56 & 0.15 \\
\hline$T+m a n$ & 446.50 & 0.37 & 42.60 & 0.38 & 555.63 & 0.16 & 554.16 & 0.09 & 546.20 & 0.18 \\
\hline$T+m o w$ & 444.14 & 0.39 & 45.83 & 0.29 & 554.26 & 0.14 & 553.32 & 0.06 & 544.65 & 0.18 \\
\hline$T+$ seed & 445.66 & 0.37 & 43.36 & 0.35 & 544.30 & 0.43 & 548.40 & 0.22 & 541.43 & 0.25 \\
\hline$T+m a n+m o w$ & 442.77 & 0.38 & 46.17 & 0.37 & 550.27 & 0.16 & 549.56 & 0.09 & 542.26 & 0.18 \\
\hline$T+m a n+s e e d$ & 444.32 & 0.36 & 43.27 & 0.43 & 540.89 & 0.43 & 544.78 & 0.24 & 538.99 & 0.26 \\
\hline$T+$ mow + seed & 441.94 & 0.38 & 46.77 & 0.35 & 539.71 & 0.42 & 543.62 & 0.22 & 537.79 & 0.25 \\
\hline$T+m a n+m o w+$ seed & 440.51 & 0.37 & 47.13 & 0.43 & 536.28 & 0.42 & 540.23 & 0.24 & 535.28 & 0.25 \\
\hline
\end{tabular}

